\title{
Antecedents of entrepreneurial intentions of electrical installation and maintenance work students' in technical colleges
}

\author{
Taiwo Olabanji Shodipe and Ifeanyi Benedict Ohanu \\ Department of Industrial Technical Education, \\ University of Nigeria, Nsukka, Nigeria
}

Intentions of electrical installation

Received 23 August 2019 Revised 1 March 2020 13 April 2020 17 May 2020

Accepted 17 May 2020

\begin{abstract}
Purpose - Extending the theory of planned behaviour and the perspective of available resources, the purpose of this study is to expatiate the influence behavioural antecedents of available resources on electrical installation and maintenance work students' (EIMW) entrepreneurial intentions (EIs) in technical colleges.

Design/methodology/approach - The study adopted a multistage sampling technique to select samples for the study. Data collected were analyzed using structural equation models in the empirical analysis.

Findings - The study showed that attitude, subjective norms, perceived behavioural control and perceived efficacy are behavioural antecedents that can be manipulated by exogenous factors to enhance EIMW students' EIs.

Originality/value - This study stirs the government and other education agencies on the need to strengthen the technical institutions through adequate funding, employment of skilled personnel and provision of up-to-date types of machinery and equipment to help the students to compete globally. Therefore, adequate application of available resources will foster positive behaviours of EIMW students towards establishing their business venture.
\end{abstract}

Keywords Entrepreneurial intentions, Resources, Behavioural antecedents, EIMW

Paper type Research paper

\section{Introduction}

Technical Vocational Education and Training (TVET) is the foundation for the entrepreneurial programme in technical institutions in Nigeria. TVET courses offered by students in technical colleges include automobile repair and maintenance, electrical works, electrical installation and maintenance works (EIMW) welding and fabrication, etc (Amedorme and Fiagbe, 2013). Ohanu et al. (2020) stated that EIMW is an area of specialization in Vocational and Technical Education programme of technical colleges in Nigeria, designed to impart knowledge and practical skills in different engineering trade areas such as house wiring (conduit and surface), coil winding and re-winding, electrical

(C) Taiwo Olabanji Shodipe and Ifeanyi Benedict Ohanu. Published in Asia Pacific Journal of Innovation and Entrepreneurship. Published by Emerald Publishing Limited. This article is published under the Creative Commons Attribution (CC BY 4.0) licence. Anyone may reproduce, distribute, translate and create derivative works of this article (for both commercial and noncommercial purposes), subject to full attribution to the original publication and authors. The full terms of this licence may be seen at http://creativecommons.org/licences/by/4.0/legalcode 
gadgets repairs, installation and maintenance of electrical machines, battery charging, installation and maintenance of electric motors, etc. Bhattacharyya and Kumar (2020) found that vocational curricula provide more practical-oriented training to the students. Despite the rigorous entrepreneurial training process in technical colleges, many of the EIMW students roam the street in search of blue-collar jobs in industries backsliding from the core objectives of entrepreneurial education and training received. Many EIMW students do not have the intention to become entrepreneurs or rather some lost their pursuit to become entrepreneurs. Nwokomah (2005) submitted that lack of financial resources, inadequate trained vocational teachers and lack of teaching resources have contributed to the unpreparedness of graduates of technical colleges for the workforce and their subsequent job performance within the workplace (Moses et al., 2017). Therefore, to extenuate these problems, the technical education custodians should provide adequate and updated resources to technical education institutions so as to meet up with the increasing demands and EIMW graduates should be financially assisted with a starting capital towards establishing their new business.

The purpose of this study is to determine the effect of behavioural antecedents of available resources on EIMW students' entrepreneurial intentions (EIs) which focusses majorly on students in technical colleges in Lagos State, a south-west region in Nigeria using the theory of planned behaviour (TPB). Ohanu et al. (2020) defined entrepreneurship as an opportunity to discover any new business and venture into it so as to make a profit by investing scarce resources. According to Alam et al. (2020) entrepreneurship as a notion has expanded from business start-up by entrepreneurs (Park, 2017) to value creation. Ohanu and Ogbuanya (2018) defined entrepreneurship as the act of establishing and managing a business venture for the purpose of making a profit. Also, Ohanu and Ogbuanya (2018) defined an entrepreneur is an individual who establishes and manages a business enterprise. Previous studies carried out on entrepreneurship have concentrated on nascent entrepreneurs, secondary students of general education, undergraduate students, postgraduate students and in other regions (developed countries) but this study focusses on technical education students in Nigeria. Also, a previous study suffers from omitted variables such as students' access to tools and equipment and access to material resources as available resources.

\section{Literature review and hypothesis development}

Theory of planned behaviour

The TPB is an established theory that is used to explain and predicts human behaviour across the human race (Ajzen, 2001). A recent study supports the validity of TPB for predicting EIs and behaviour (Schlaegel and Koenig, 2014), that is the reason for the application of the theory across all edifice, most especially entrepreneurship to predict individuals behaviour to venture into creating their own business. The TPB proposed that EIs are developed on three antecedents (Mirjana et al., 2018). They include attitude towards behaviour (Ana et al., 2000), subjective norms (Linán and Chen, 2009), and perceived behavioural control (Walker et al., 2013).

As a result of previous research on behavioural antecedents and based on entrepreneurial activities amongst EIMW students in technical colleges in Lagos State, south-west zone, Nigeria, we aim to reinforce the result of other researchers who have found a significant influence of attitude, subjective norms and perceived behavioural control. Therefore, we hypothesize that: 
H1. The more positive EIMW students' attitude towards starting a new business, the higher their EIs.

H2. The more positive EIMW students' subjective norms towards starting a new business, the higher their EIs.

H3. The more positive EIMW students perceived behavioural control towards starting a new business, the higher their EIs.

Intentions of electrical installation

\section{Access to resources}

Educational resources are supports in technical institutions that emerge as an efficient way of obtaining necessary knowledge about entrepreneurship. Wang and Wong (2004) point out the fact that entrepreneurial dreams of many students are hindered by inadequate preparation of the academic institution or rather inadequate institutional resources. The education system of technical colleges plays vital roles in identifying and shaping the entrepreneurial trait (Ibrahim and Soufani, 2002), by providing the required human resources/expertise, modern tools and equipment that meets the students entrepreneurial needs, materials, stimulating workshop environment and adequate financing. Menzies and Paradi (2003) pointed out that entrepreneurship education, especially education that provides technological training, is crucial to enhance entrepreneurs' innovation skills in an increasingly challenging environment. Having access to a better environment, students' financial prowess triggers their EIs. Aragon-Sanchez et al. (2017) explained that wealth and income are positively associated with students' EIs. This simply means that learners who are well funded at home can save up their money to start up immediately after entrepreneurial training while lack of access to such may hamper the establishment of their firm. Therefore, we hypothesize the following resources to influence behavioural antecedents towards establishing a new business:

H4. The more access to human resources EIMW students have, the more positive the students perceived efficacy, subjective norms and attitudes.

H5. The more access to financial resources EIMW students have to start a business, the more positive perceived efficacy, attitude and perceived behavioural control.

H6. The more access to material resources EIMW students have to start a business, the more positive their perceived behavioural control, perceived efficacy and subjective norms.

H7. The more access to tools and equipment EIMW students have to start a business, the more positive their perceived behavioural control, subjective norms and attitude.

\section{Gender}

The study of EIMW in Nigeria technical colleges are faced with diverse misconceptions and gender bias. This serves as the basis for low enrolment of the women in industrial technical education and lacks the enabling knowledge and skills in EIMW to contribute adequately towards socio-economic development in Nigeria. In the quest to close the gender gap, more women than men are encouraged to engage in entrepreneurship (Sahinidis et al., 2012). Therefore, it was hypothesized that: 
APJIE 14,2

H8. EIMW students' gender influences their access to utilization of resources to achieve their EIs (Figure 1).

\section{Methodology}

The study was carried out in the six technical colleges in Lagos state Nigeria. The technical colleges are institutions where entrepreneurial education/pieces of training are administered to the students. These pieces of training empower the students to be gainfully used by being owners of a business, employers of labours or being an employee. Students in their second and third year are selected because they have been introduced to one form of entrepreneurial training or the other which made them be the best choice for this study.

\section{Sample}

Data were collected from a sample of 250 out of 965 EIMW students using a structured questionnaire which combined an adapted and self-developed questionnaire as an instrument. Using a multistage sampling technique, samples were selected from three schools randomly selected from the six technical colleges. The questionnaire was administered in the presence of the school counsellor by the researchers.

\section{Instrument for data collection}

The questionnaire has two parts; part one ascertains demographic contents and the second part covers the antecedents of intentions according to the TPB and is based on seven-point Likert rating scale, ranging from (strongly agree $=7-$ strongly disagree $=1$ ). Based on the adapted instruments, the number of items is, thus: attitude - five items, (Linán and Chen, 2009); subjective norm - four items, (Krueger et al.2000); perceived behavioural control - five items, (Linán and Chen, 2009); financial capital - three items and human capital - four items (Ayob et al., 2013); EIs - five items (Linán and Chen, 2009); perceived efficacy - four items (Wilson et al., 2007). The researchers developed items in the following antecedents of intention: access to materials - four items; and access to tools and equipment - four items.

\section{Results}

The results presented were analyzed running the descriptive statistics; correlations, regression analysis and AMOS were used to test the hypothesis. The respondent's age ranged between $10-14$ years (59\%), 15-19 years (66\%), 20-24 years ( $8 \%$ ) and 25 years above $(2.4 \%)$ with a mean $(\mathrm{X}=1.89)$ and standard deviation $(\mathrm{SD}=0.63)$, it also showed that 235 $(94.8 \%)$ respondents from the sample are men while $13(5.2 \%)$ are women, this may be as a

Figure 1.

Schema for antecedents of EIs of EIMW students'

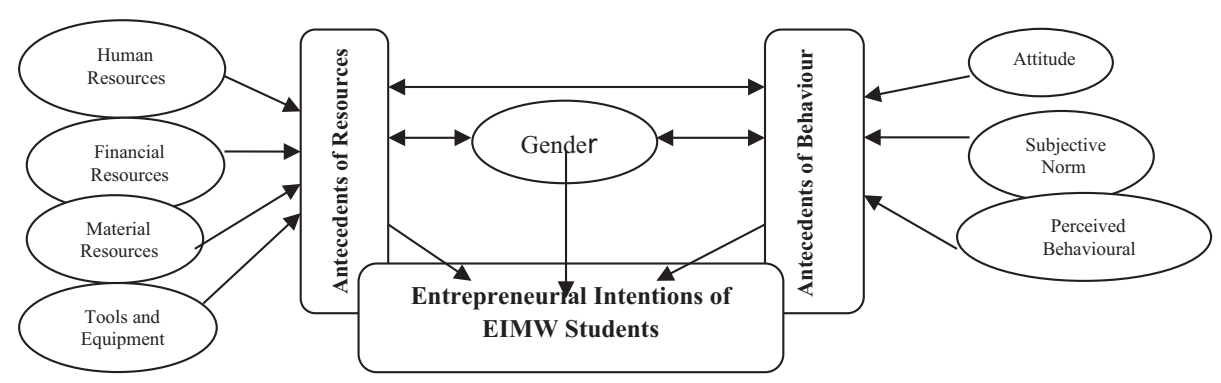


result of the nature of technical education. In total, $68.4 \%$ of the sample are in their Year 2 and $31.6 \%$ in their Year 3.

\section{Validity and reliability tests}

The instrument for the study was subjected to content validity. A factor analysis was done on the variables with principal component analysis $(\mathrm{PCA})$ and the unrotated factor solution with eigenvalues greater than one. The measurement model was estimated using confirmatory factor analysis (CFA) to test the goodness of fit of the measurement scale. The CFA confirmed the existence of the hypothesized factor structure with fit indices supporting an adequate fit between the model and the data, therefore, there is a good fit and the measurement model is robust, Satorra-Bentler $\chi^{2}(250)=334.42(p=0.000)$ (Byrne, 2001), the Bentler-Bonett normed fit index is robust (NFI) $=0.553$ (Lomax and Schumacker, 2012), the Tucker-Lewis index is robust (TLI) $=0.27$ (Prudon, 2015), the comparative fit index is robust $(\mathrm{CFI})=0.57$ (Hair et al., 2010), the Bollen's fit index is robust $(\mathrm{IFI})=0.59$ (Kline, 2005), the goodness of fit index (GFI) $=0.80$ (Schermelleh-Engel et al., 2003) and the root mean square error of approximation is robust (RMSEA) $=0.15$ (Schermelleh-Engel et al., 2003). A scrutinized analysis of the variables and items shows that all have significant standardized coefficient values with a $p$-value $<0.01$. Conclusively, the model is suitable for measuring the specified constructs based on the results.

\section{Instrument validity}

From the responses of the questionnaire items by EIMW students, the latent dimensions were examined using the PCA method. It explores the patterns of relationship between the behavioural antecedents and resources that are not correlated with one another and also avoid multicollinearity problem in our regressions. The descriptive analysis of the data and the correlation matrix are presented in Table 2. The correlation coefficients are below discriminant validity; hence this eliminates the problem of multicollinearity. To apply the PCA method, the correlation matrix of the involving variables was subjected to various tests to show the adequacy of the data. The KMO statistic for the study is 0.800 , a value greater than the recommended value of 0.50 and Bartlett's test is statistically significant at the $p<$ 0.001 level (Barba-Sanchez and Atienza-Sahuquillo, 2018).

Table 1 shows the convergent validity [composite reliability $(\mathrm{CR})$ and average variance extracted (AVE)] and discriminant validity of entrepreneurial intention factors. From the factor analysis, we obtain nine factors with six components extracted whose eigenvalues

\begin{tabular}{llcccc}
\hline \multirow{2}{*}{ Constructs } & \multicolumn{2}{l}{ Convergent validity } & & \\
& AVE & CR & Discriminant validity & Cronbach's Alpha $(\alpha)$ & \\
\hline Attitude & 0.36 & 0.69 & 0.61 & 0.743 \\
Subjective norms & 0.52 & 0.76 & 0.72 & 0.841 \\
Perceived behavioural control & 0.41 & 0.67 & 0.64 & 0.765 \\
Financial resources & 0.51 & 0.75 & 0.71 & 0.764 & \\
Human resources & 0.61 & 0.82 & 0.78 & 0.752 & Table 1. \\
Material resources & 0.56 & 0.83 & 0.74 & 0.744 & Convergent and \\
Tools and equipment & 0.38 & 0.71 & 0.62 & 0.804 & discriminant validity \\
Entrepreneurial intentions & 0.34 & 0.10 & 0.58 & 0.748 & \\
Perceived efficacy & 0.43 & 0.69 & 0.65 & & \\
\hline
\end{tabular}

\section{Intentions of electrical installation}

131 
APJIE 14,2

Table 2.

Means, standard deviation and a correlation table greater than 1 . The factors extracted using the PCA method accounts for $51.8 \%$ of the total variance.

The CR of a latent variable is formed by reliabilities of all measure variables which represent an internal consistency of a latent variable (Chang et al., 2012). Convergent validity is adequate when constructs present an AVE which is higher than 0.5 and CR greater than 0.7 (Fornell and Larcker, 1981). Also, it can be verified when items loading on their associated factors are well above 0.5 (Hair et al., 1995). In the rotated component matrix, almost all the constructs have a factor loading value that exceeds 0.70 . In reality, it can be found that several measurement items of an estimated model could have loadings below 0.7 (Sorebo et al., 2009). The two indicators to evaluate convergent validity are CR and AVE (Lee et al., 2007). As shown in Tables 1 and 2, the square root of the AVE value for the variables is consistently greater than their correlations and this shows satisfactory discriminant validity among variables.

\section{Confirmatory factor analysis}

The result of the confirmatory factor analysis shows PCA with the correlation matrix of the variables submitted to various tests to highlight its adequacy as shown in the tables below.

Table 2 shows the Pearson correlation matrix of the constructs. The result shows that there is a positive relationship between attitude and EIs. Also, it shows a very low positive relationship between subjective norms and EIs. There is a low positive relationship between human resources and perceived efficacy, attitude and no significant relationship with subjective norms. There is a moderate positive relationship between financial resources and perceived efficacy, low positive relationship with attitude and perceived behavioural control. More also, there is no significant relationship between material resources and perceived behavioural control, perceived efficacy, subjective norms. Finally, there is a low positive relationship between tools and equipment and perceived behavioural control, subjective norms and attitude.

Regression weight for the structural model

In view of the model path analysis, the standardized regression estimate of students' EIs describes the level of degree of influence of resources and behavioural antecedents towards

\begin{tabular}{|c|c|c|c|c|c|c|c|c|c|c|c|}
\hline Variables & $\bar{X}$ & $\mathrm{SD}$ & 1 & 2 & 3 & 4 & 5 & 6 & 7 & 8 & 9 \\
\hline TT & 5.79 & 0.91 & 1 & & & & & & & & \\
\hline UN & 5.31 & 1.44 & $0.252^{* *}$ & $=1$ & & & & & & & \\
\hline $\mathrm{PBC}$ & 5.78 & 0.83 & $0.475^{* *}$ & $0.272 * *$ & 1 & & & & & & \\
\hline AFR & 5.61 & 1.19 & $0.451^{* *}$ & $=0.198 * *$ & $0.348^{* *}$ & 1 & & & & & \\
\hline AHR & 5.50 & 1.97 & $0.273 * *$ & $=0.121$ & $0.184^{* *}$ & $0.259 * *$ & 1 & & & & \\
\hline ATM & 4.75 & 1.20 & 0.030 & -0.100 & 0.049 & 0.059 & 0.042 & 1 & & & \\
\hline ATE & 5.89 & 1.05 & $0.368^{* *}$ & $=0.205^{* *}$ & $0.355^{* * *}$ & $0.451^{* *}$ & $0.390 * *$ & -0.020 & 1 & & \\
\hline EI & 5.02 & 1.11 & $0.501^{* *}$ & $0.166^{* * *}$ & $0.385^{* * *}$ & $0.357^{* * *}$ & $0.260^{* * *}$ & -0.112 & $0.352 * *$ & 1 & \\
\hline PE & 5.79 & 0.96 & $0.390 * *$ & $0.240 * *$ & $0.487^{* * *}$ & $0.457 * *$ & $0.279 * *$ & 0.083 & $0.521^{* *}$ & $0.529 * *$ & 1 \\
\hline Gender & 1.05 & 0.22 & $-0.307^{* *}$ & $=0.089$ & $-0.354^{* *}$ & $-0.273 * *$ & $-0.151 *$ & -0.020 & $-0.238 * *$ & $-0.457 * *$ & -0.361 \\
\hline
\end{tabular}

Notes: $* p<0.05 ; * * p<0.01 ; n=250$, ATT $=$ attitude, $\mathrm{SUN}=$ subjective norms, $\mathrm{PBC}=$ perceived behavioural control, $\mathrm{AFR}=$ access to financial resources, $\mathrm{AHR}=$ access to human resources, $\mathrm{ATM}=$ access to materials, $\mathrm{ATE}=$ access to tools and equipment, $\mathrm{EI}=$ entrepreneurial intentions and $\mathrm{PE}=$ perceived efficacy 
EIs. The critical ratio is the commonly recommended basis for testing the statistical significance of SEM components with $\mathrm{CR}$ values beyond \pm 2.58 establishing significance at $p<0.01$ level (Byrne, 2001).

Table 3 path coefficient and hypothesis test for the entrepreneurial intention model. Electrical installation maintenance and work students' attitude regress significantly and positively with their entrepreneurial intention, therefore, $H 1$ is accepted. Electrical installation maintenance and work students' subjective norms do not regress significantly with entrepreneurial intention, therefore, $H 2$ is rejected. Also, EIMW students perceived behavioural control does not regress significantly with EIs, therefore, $H 3$ is rejected. Access to available human resources does not regress significantly with EIMW students' perceived efficacy, subjective norms and attitude, therefore, $H 4$ is rejected. Access to available financial resources regress significantly and positive with EIMW students' perceived efficacy, attitude and perceived behavioural control, therefore, H5 is accepted. Access to available material resources does not regress significantly with EIMW students' perceived behavioural control, perceived efficacy, subjective norms, therefore, $H 6$ is rejected. EIMW students' access to tools and equipment regress significantly and positive with their perceived behavioural control, subjective norms and attitude, therefore, $H 7$ is partially accepted as access to tools and equipment does not regress significantly with their subjective norms. EIMW students' gender does not regress significantly with their EIs, therefore, $H 8$ is rejected.

\section{Discussion}

This paper sought to complement the different studies on TPB and the major roles played by its antecedents to ensure the establishment of new businesses by individuals. The study found some institutional resources have a significant influence on some students' behaviour towards EIs.

The result of the finding shows that available resources have a significant and nonsignificant influence on EIMW students' attitude towards entrepreneurship to establish a new business. Therefore, $H 1, H 5$ and $H 7$ were accepted to have a significant influence. This result is consistent with the findings of Liñan (2008) which emphasized that students

\begin{tabular}{|c|c|c|c|c|c|c|c|c|c|c|}
\hline Hypothesis & Paths & & $\begin{array}{l}\text { Path } \\
\text { coefficient }\end{array}$ & B & S.E & CR & $p$ & $\beta$ & Result & \\
\hline 1 & ATT & EI & 0.336 & 0.613 & 0.066 & 5.080 & 0.000 & 0.501 & Accepted & \\
\hline 2 & SUN & EI & -0.033 & 0.129 & 0.037 & -0.897 & 0.370 & 0.166 & Rejected & \\
\hline 3 & $\mathrm{PBC}$ & EI & 0.019 & 0.063 & 0.071 & 0.272 & 0.786 & 0.045 & Rejected & \\
\hline \multirow[t]{3}{*}{4} & AHR & $\mathrm{PE}$ & 0.022 & 0.408 & 0.025 & 0.900 & 0.368 & 0.199 & Rejected & \\
\hline & & SUN & 0.036 & 0.035 & 0.044 & 0.802 & 0.422 & 0.025 & Rejected & \\
\hline & & ATT & 0.063 & 0.410 & 0.025 & 2.511 & 0.012 & 0.189 & Rejected & \\
\hline \multirow[t]{3}{*}{5} & AFR & $\mathrm{PE}$ & 0.209 & 0.387 & 0.041 & 5.074 & 0.000 & 0.314 & Accepted & \\
\hline & & ATT & 0.274 & 0.398 & 0.041 & 6.602 & 0.000 & 0.305 & Accepted & \\
\hline & & $\mathrm{PBC}$ & 0.151 & 0.075 & 0.039 & 3.904 & 0.001 & 0.051 & Accepted & \\
\hline \multirow[t]{3}{*}{6} & ATM & $\mathrm{PBC}$ & 0.027 & 0.059 & 0.038 & 0.695 & 0.487 & 0.039 & Rejected & \\
\hline & & $\mathrm{PE}$ & 0.059 & 0.120 & 0.041 & 1.437 & 0.151 & 0.096 & Rejected & \\
\hline & & SUN & -0.129 & -0.112 & 0.073 & -1.776 & 0.076 & -0.134 & Rejected & \\
\hline \multirow[t]{3}{*}{7} & ATE & $\mathrm{PBC}$ & 0.172 & 0.283 & 0.044 & 3.933 & 0.009 & 0.216 & Accepted & \\
\hline & & $\mathrm{PE}$ & 0.191 & 0.062 & 0.083 & 2.291 & 0.022 & 0.085 & Rejected & Table 3. \\
\hline & & SUN & 0.169 & 0.281 & 0.047 & 3.611 & 0.003 & 0.244 & Accepted & Path coefficients and \\
\hline 8 & Gender & EI & -0.006 & -2.295 & 0.081 & -0.072 & 0.942 & -0.457 & Rejected & hypothesis test \\
\hline
\end{tabular}
electrical installation

133
Intentions of 
APJIE 14,2

attitude towards entrepreneurship is an incubator of their awareness of the importance and value of entrepreneurship. Again, Billal et al. (2019) identified the attitudes of individuals in companies to be among the behavioural barriers of e-Commerce. Also, Douglas and Shepherd (2002) found out that individuals with positive attitude bear risk crave for independence and have strong intents to become entrepreneurs. However, $H 4$ is rejected to have significant influence. This finding is in consonance with the study of Ridha et al. (2017), who found out an insignificant influence of attitude towards entrepreneurship amongst 198 young entrepreneurs of Agricultural Young Entrepreneurship Growing Programme in Indonesia.

This study suggests that there is a low societal perception (subjective norms) of entrepreneurship which gives rise to the poor influence on students' EIs and it can be seen in $H 2, H 4$ and $H 6$ that subjective norm was rejected to have had a significant influence on students' EIs, human and material resources. However, in previous studies, subjective norms have a significant influence on students' EIs (Mirjana et al., 2018). Also, the finding of this study supports the findings of Linán and Chen (2009) from a sample of 387 university students from Spain and Taiwan that subjective norms do not positively influence students' EIs. This disparity of the influence of subjective norms on EIs and some other variables may be as a result of the questionnaire items do not properly operationalize subjective norms. However, $H 7$ substantiates a significant influence of tools and equipment on subjective norms.

Perceived behavioural control is the way people view themselves about establishing a new business and contending obstacles. The result of the study shows that PBC is significant with $H 5$ and $H 7$. The result of the study aligns with the previous study of Terry and O'Leary (1995) whose study on 146 undergraduate students shows that perceived behavioural control have a significant moderating effect between behavioural intentions and the actual behaviour. Also, the result of the study shows that PBC is nonsignificant with $H 3$ and $H 6$. The finding of the study aligns with the previous study of Ridha et al. (2017), whose study of PBC show a non-significant relationship with the young agricultural entrepreneurs' EIs. This is an indication that some EIMW students do not have positive thought of establishing their own business despite their access to material resources, they assume more obstacle than success in their chosen entrepreneurial career.

The effect of perceived efficacy has been positive and significant in previous kinds of literature Karlsson and Moberg (2013). In this study, EIMW students' perceived efficacy is shown to be insignificant with their EIs despite access to human and material resources. Therefore, H4, H6 and H7 are rejected. Also, the result of the study shows that H5 is significant. That is available financial resources stirs students' perceived efficacy towards starting their own business. This study agrees with previous studies that perceived efficacy influences individuals' level of motivation, which has been found to occupy a distinct place as a fundamental determinant of behaviour (EL-Zohiry and Abd-Elbaqy, 2019), determines the effort that will be exerted on a task and how he will persevere in the face of obstacles. Likewise, it is the strongest factor that influences students' choice to be an entrepreneur (Bandura, 2012).

Also, many people think that EIMW is meant for men. This perception contributes to a low enrolment of women into the programme (Agu and Omenyi, 2013). In the course of the study, 237 students for the study are men while 13 students for the study are women which give a high rise in dominion by the male students. Despite the rising male population in EIMW, there is still an insignificant relationship between their gender and entrepreneurial intention. 


\section{Conclusion}

New venture creation starts with intentions. The individual intention is influenced by a certain level of planned behaviour (Krueger et al., 2000). Therefore, it is evident in this study that EIMW students' behaviour towards starting a new business is influenced by available resources within the school.

The result of the study will add more to the existing robustness of TPB considering the influence of available school resources. This shows that attitude, subjective norms, perceived behavioural control and perceived efficacy are behavioural antecedents that can be manipulated by the exogenous factor to enhance EIMW students' EIs. Also, it is an eyeopener to the government and other education agencies on the need to further strengthen the technical institutions through adequate funding, employment of skilled personnel and provision of up-to-date types of machinery and equipment to help the students to compete globally. Technical teachers will see the need to impact the right skill, attitude and norms on the students as the right attitude will enhance their EIs. Parents will be motivated to augment the school effort on the provision of necessary resources to the students which could be used personally at home or be taken to school during their practical session. Technical institutions should ensure good maintenance culture to prolong the life span of the available tools and equipment and adequate training should be given to avoid malhandling of tools and machines.

The current study encountered some limitations, the population of the students offering EIMW in technical colleges are few compared to general education students, thus, the sample size for the study is affected. A higher number of the sample size are not fluent in reading and speaking English language, so I had to read and interpreted for these set of students which gulp buck of the time for the research. Further research can be carried out on behavioural antecedents between resources and EIs amongst retiring civil servants in the south-west zone of the country with a concentration on their work experience, human resource relationship and the role of organization structure as factors that may influence their behaviour towards new venture creation.

\section{References}

Agu, N.N. and Omenyi, A.S. (2013), "Gender enrolment status in higher education courses: a situation assessment and analysis of a South Eastern federal university", Journal of Emerging Trends in Educational Research and Policy Studies (JETERAPS), Vol. 4 No. 3, pp. 517-524.

Ajzen, I. (2001), "Nature and operation of attitudes", Annual Review of Psychology, Vol. 52 No. 1, pp. 27-58.

Alam, M.Z., Kousar, S., Shabbir, A. and Kaleem, M.A. (2020), "Personality traits and intrapreneurial behaviour: moderated role of knowledge sharing behaviour in diverse group of employees in developing country", Asia Pacific Journal of Innovation and Entrepreneurship, Vol. 14 No. 1, pp. 31-46.

Amedorme, S.K. and Fiagbe, Y.A.K. (2013), "Challenge facing technical and vocational education in Ghana", International Journal of Scientific and Technology Research, Vol. 2 No. 6, pp. 253-255.

Ana, A., Chandler, G., Jansen, E. and Mero, N. (2000), "Women business owners in traditional and nontraditional industries", Journal of Business Venturing, Vol. 15 No. 3, pp. 279-303.

Aragon-Sanchez, A., Baixauli-Soler, S. and Carrasco-Hernandez, A.J. (2017), "A missing link: the behavioral mediators between resources and entrepreneurial intentions", International Journal of Entrepreneurial Behavior and Research, Vol. 23 No. 5, pp. 752-768.

Ayob, A., Hussain, A. and Majid, R.A. (2013), "A review of research on creative teachers in higher education”, International Education Studies, Vol. 6 No. 6, pp. 61-65. 
APJIE 14,2

Bandura, A. (2012), "On the functional properties of perceived self-efficacy revisited", Journal of Management, Vol. 38 No. 1, pp. 9-44.

Barba-Sanchez, V. and Atienza-Sahuquillo, C. (2018), "Entrepreneurial intention among engineering students: the role of entrepreneurship education”, European Research on Management and Business Economics, Vol. 24 No. 1, pp. 53-61.

Bhattacharyya, A. and Kumar, N. (2020), "Who is more entrepreneurial? A comparative study of vocational and academic students", Asia Pacific Journal of Innovation and Entrepreneurship, Vol. 14 No. 1, pp. 15-30.

Billal, H.M., Shin, H.K. and Sim, S.J. (2019), "Critical success factors (CSF) on e-commerce adoption in Bangladesh SMEs”, Management Review: An International Journal, Vol. 14 No. 1, pp. 51-81.

Byrne, B.M. (2001), Structural Equation Modeling with AMOS: Basics Concepts, Applications and Programming, Lawrence Erlbaum Associates, Mahwah, NJ.

Chang, C.C., Yan, C.F. and Tseng, J.S. (2012), "Perceived convenience in an extended technology acceptance model: mobile technology and english learning for college students", Australasian Journal of Educational Technology, Vol. 28 No. 5, pp. 809-826.

Douglas, E.J. and Shepherd, D.A. (2002), "Self-employment as a career choice: attitudes, entrepreneurial intentions, and utility maximization", Entrepreneurship Theory and Practice, Vol. 26 No. 3, pp. 81-90.

El-Zohiry, A.A. and Abd-Elbaqy, K.Y. (2019), "The moderating effect of intrinsic motivation on the relationship between psychological capital and organizational citizenship behaviors", Management Review: An International Journal, Vol. 14 No. 2, pp. 4-32.

Fornell, C. and Larcker, D.F. (1981), "Evaluating structural equation models with unobservable variables and measurement error", Journal of Marketing Research, Vol. 18 No. 1, pp. 39-50.

Hair, J.F., Anderson, R.E., Tatham, R.L. and Black, W.C. (1995), Multivariate Data Analysis, Prentice Hall, Englewood Cliffs, NJ.

Hair, J.F., Black, W.C., Babin, B.J. and Anderson, R.E. (2010), Multivariate Data Analysis, a Global Perspective, 7th ed., Pearson Education, NJ.

Ibrahim, A.B. and Soufani, K. (2002), "Entrepreneurship education and training in Canada: a critical assessment", Education + Training, Vol. 44 Nos 8/9, pp. 421-430.

Karlsson, T. and Moberg, K. (2013), "Improving perceived entrepreneurial abilities through education: exploratory testing of an entrepreneurial self-efficacy scale in a pre-post setting", The International Journal of Management Education, Vol. 11 No. 1, pp. 1-11.

Kline, R.B. (2005), Principles and Practice of Structural Equation Modeling, 2nd ed., The Guilford Press, New York, NY.

Krueger, N.F., Reilly, M.D. and Carsrud, A.L. (2000), “Competing models of entrepreneurial intentions”, Journal of Business Venturing, Vol. 15 Nos 5/6, pp. 411-432.

Lee, M.K.O., Cheung, C.M.K. and Chen, Z. (2007), "Understanding user acceptance of multimedia messaging services: an empirical study", Journal of the American Society for Information Science and Technology, Vol. 58 No. 13, pp. 2066-2077.

Liñán, F. (2008), "Skill and value perceptions: how do they affect entrepreneurial intention?", International Entrepreneurship and Management Journal, Vol. 4 No. 3, pp. 257-272.

Linán, F. and Chen, Y.W. (2009), "Development and cross-cultural application of a specific instrument to measure entrepreneurial intentions", Entrepreneurship Theory and Practice, Vol. 33 No. 3, pp. 593-617.

Lomax, R.G. and Schumacker, R.E. (2012), A Beginner's Guide to Structural Equation Modeling, Routledge Academic New York, NY.

Menzies, T.V. and Paradi, C.J. (2003), "Entrepreneurship education and engineering students - career path and business performance", The International Journal of Entrepreneurship and Innovation, Vol. 4 No. 2, pp. 121-132. 
Mirjana, P.B., Ana, A. and Marjana, M.S. (2018), "Examining determinants of entrepreneurial intentions in Slovenia: applying the theory of planned behaviour and an innovative cognitive style", Economic Research-Ekonomska Istraživanja, Vol. 31 No. 1, pp. 1453-1471.

Moses, D., Dariso, D.K., Yaduma, P.S. and Agbu, D. (2017), "Industrial installation skills acquired and job performance of graduates of electrical installation and maintenance works trade of technical colleges in North Eastern Nigeria", The International Journal of Engineering and Science, Vol. 6 No. 6, pp. 1-8.

Nwokomah, C.G. (2005), "Strategy for attaining functional vocational and technical education in the 21st century in Nigeria", Journal of Education in Developing Areas, Vol. 1 No. 14, pp. 53-61.

Ohanu, I.B. and Ogbuanya, T.C. (2018), "Determinant factors of entrepreneurship intentions of electronic technology education students in Nigerian universities", Journal of Global Entrepreneurship Research, Vol. 8 No. 1, pp. 1-17.

Ohanu, I.B., Shodipe, T.O., Chukwu, D.U. and Chukwuma, J.N. (2020), "Impact of behavioural factors as related to available resources on entrepreneurial intentions of electrical installation and maintenance works students", International Journal of Engineering Education, Vol. 36 No. 1(A), pp. 142-154.

Park, C. (2017), "A study on effect of entrepreneurship on entrepreneurial intention: focusing on ICT majors", Asia Pacific Journal of Innovation and Entrepreneurship, Vol. 11 No. 2, pp. 159-170.

Prudon, P. (2015), "Confirmatory factor analysis as a tool in research using questionnaire: a critique", Comprehensive Psychology, Vol. 4 No. 10, pp. 1-19.

Ridha, R.N. and Wahyu, B.P. (2017), "Entrepreneurship intention in agricultural sector of young generation in Indonesia”, Asia Pacific Journal of Innovation and Entrepreneurship, Vol. 11 No. 1, pp. 76-89.

Sahinidis, A.G., Giovanis, A.N. and Sdrolias, L. (2012), "The role of gender on entrepreneurial intention among students: an empirical test of the theory of planned behaviour in a Greek university", International Journal of Integrated Information Management, Vol. 1 No. 1, pp. 61-79.

Schermelleh-Engel, K., Mossbrugger, H. and Müller, H. (2003), "Evaluating the fit of structural equation models: test of significance and descriptive goodness-of-fit measures", Methods of Psychological Research Online, Vol. 8 No. 2, pp. 23-74.

Schlaegel, C. and Koenig, M. (2014), "Determinants of entrepreneurial intent: a meta-analytic test and integration of competing models", Entrepreneurship Theory and Practice, Vol. 38 No. 2, pp. 291-332.

Sorebo, O., Halvari, H., Gulli, V.F. and Kristiansen, R. (2009), "The role of self-determination theory in explaining teachers' motivation to continue to use e-learning technology", Computers and Education, Vol. 53 No. 4, pp. 1177-1187.

Terry, D.J. and O'Leary, J.E. (1995), “The theory of planned behaviour: the effects of perceived behavioural control and self-efficacy", British Journal of Social Psychology, Vol. 34 No. 2, pp. 199-220.

Walker, J.K., Jeger, M. and Kopecki, D. (2013), "The role of perceived abilities, subjective norm and intention in entrepreneurial activity", The Journal of Entrepreneurship, Vol. 22 No. 2, pp. 181-202.

Wang, C.K. and Wong, P.K. (2004)," "Entrepreneurial interest of university students in Singapore", Technovation, Vol. 24 No. 2, pp. 163-172.

Wilson, F., Kickul, J. and Marlino, D. (2007), "Gender, entrepreneurial self-efficacy, and entrepreneurial career intentions: implications for entrepreneurship education”, Entrepreneurship Theory and Practice, Vol. 31 No. 3, pp. 387-401.

\section{Corresponding author}

Ifeanyi Benedict Ohanu can be contacted at: ifeanyi.ohanu@unn.edu.ng

For instructions on how to order reprints of this article, please visit our website:

www.emeraldgrouppublishing.com/licensing/reprints.htm

Or contact us for further details: permissions@emeraldinsight.com
Intentions of electrical installation 